\title{
MODEL PENGAWASAN DPRD TERHADAP PEMERINTAH DAERAH DI KABUPATEN SINJAI
}

\author{
Juharni \\ Dosen Fisipol Universitas Bosowa Makassar \\ Umar \\ Dosen STISIP Muhammadiyah Sinjai \\ Email: Umarcongge67@gmail.com
}

\begin{abstract}
ABSTRAK
Penelitian ini berjudul tentang Model pengawasan DPRD terhadap Pemerintah daerah di Kabupaten Sinjai. Penelitian ini dilakukan dengan maksud untuk mengetahui bagaimana sesungguhnya efektifitas model pengawasan DPRD terhadap pemerintah daerah, dengan melakukan analisis terhadap konsep utama, tentang model pengawasan DPRD terhadap pemerintah di Kabupaten Sinjai. Penelitian ini menggunakan pendekatan kualitatif, jenis studi kasus dengan teknik pengumpulan data melalui wawancara yang mendalam dan yang menjadi informan dalam penelitian ini adalah anggota DPRD, Sekretaris daerah kabupaten Sinjai, Bagian pemerintahan dan Pembangunan, tokoh masyarakat, pimpinan partai (politisi), SKPD, LSM, KOPEL, pihak ketiga (Kontrakor). Analisis data secara deskriptif kualitatif melalui teknik pengolahan data dengan tahapan reduksi, display dan verifikasi data. Dari hasil penelitian ini menunjukkan bahwa DPRD kabupaten Sinjai tidak memiliki mekanisme atau model khusus dalam menjalankan pengawasan terhadap perjanjian antara pemerintah dengan pihak ketiga di Kabupaten Sinjai. Oleh karena itu peneliti telah mengajukan gagasan atau konsep tentang mekanisme pengawasan sebagaimana telah dikemukakan pada hasil penelitian.
\end{abstract}

Kata Kunci: Model dan Pengawasan DPRD, dan Pemerintah daerah.

\section{PENDAHULUAN}

Dewan Perwakilan Rakyat Daerah (DPRD) adalah merupakan salah satu unsur penentu atas keberhasilan pelaksanaan pemerintahan di daerah, karena DPRD adalah merupakan bahagian dari pemerintah daerah dan mitra dari eksekutif dalam menjalankan fungsi pemerintahan. Dalam posisinya sebagai mitra pemerintah daerah telah diatur didalam undangundang tentang fungsi dan peran yang harus diemban dalam menjalankan tugasnya sebagai representasi dari masyarakat yang diweakilinya. Ada tiga fungsi yang menjadi kewenagan DPRD untuk membantu pemerintah dalam menjalankan roda pemerintahan, yakni fungsi legislasi, fungsi anggaran dan fungsi pengawasan.

Dalam sejarah perkembangan fungsi dan peran DPRD sebagai mitra pemerintah, mulai sejak pemerintahan orde baru hingga orde reformasi seperti sekarang ini, ada kecenderungan sebahagian masyarakat menilai bahwa ketiga fungsi tersebut di atas, satu diantaranya dianggap kurang berjalan secara maksimal, yakni fungsi pengawasan (controlling), fungsi tersebut bagi 
sebahagian orang dianggap tidak maksimal, karena secara faktual DPRD dianggap sangat lemah dan kurang mempu untuk melakukan penekanan atau dianggap kurang mampu untuk mengurangi tingkat penyelewengan yang dilakukan pihak eksekutif dalam menjalankan tugasnya selaku eksekutor, hal ini ditandai dengan masih dijumpainya berbagai kecurangan, ketidakadilan, Nepotisme dan korupsi yang cukup signifikan, yang kemudian pada ahirnya akan menggerogoti kehidupan masyarakat secara umum, padahal sangat jelas telah diatur didalam undang-undang nomor 32 Tahun 2004 tentang pemerintahan Daerah dan undangundang Nomor 27 tahun 1999 tentang MPR,DPR,DPD dan DPRD Propinsi/Kabupaten Kota, menerangkan bahwa anggota Legislatif memiliki tiga fungsi, khususnya fungsi pengawasan, yang dalam menjalankan fungsi ini, DPRD memiliki kewenangan secara politis untuk melakukan kontrol terhadap pemerintah dalam bentuk memberikan teguran atau arahan atas kebijakan yang akan dijalankan oleh pemerinrtah.

Secara umum fungsi pengawasan bertujuan untuk mengarahkan agar apa yang telah direncanakan sebelumnya dapat berjalan secara maksimal sesuai apa yang menjadi harapan bersama (LAN: 143.2008) demikian pula halnya dengan fungsi pengawasan DPRD, meskuipun hanya pengawasan yang bersifat politis, akan tetapi pada pengawasan ini juga diharapkan akan dapat menjadi kendali bagi pemerintah dalam menjalankan sistem dan mekanisme pemerintahan. Hal ini senada dengan pendapat Syamsi (1998:108) yang mengatakan bahwa pengawasan adalah fungsi manajemen yang mengusahakan agar pekerjaan kegiatan terlaksana sesuai dengan rencana, instruksi, pedoman, patokan peraturan atau hasil yang telah ditetapkan sebelumnya.

Secara khusus Pengawasan Legislatif, (DPRD) pada hakekatnya adalah lembaga pengawas yang bertugas mengawasi tindakan pemerintah daerah provinsi dan Kabupaten/Kota. Pengawasan legislatif ini tidak terbatas pada tatacara pemerintahan saja, tetapi juga terhadap tatacara penyelenggaraan keuangan daerah. Pengawasan legislatif merupakan pengawasan politik terhadap penyelenggaraan pemerintahan daerah. Sebagai mitra kerja eksekutif, DPRD perlu memberikan bantuan agar pelaksanaan amanat Rencana Pembangunan Jangka Menengah Daerah (RPJMD) oleh pemerintah daerah dapat tercapai secara efisien dan efektif dari berbagai sudut pandang termasuk politik.

Kendatipun pengawasan legislatif telah diupayakan secara maksimal, akan tetapi hasil yang dicapai dianggap belum maksimal oleh berbagai pihak, (Pen) yang ditandai dengan masih ditemukannya berbagai kelemahan dan kekuraangan pada tahap implementasi kebijakan pemerintah khususnya mengenai kelemahan pihak DPRD dalam mengawasi jalannya perjanjian antara pemerintah dengan pihak ketiga di Kabupaten Sinjai, dan masih dijumpainya pula kelemahan-kelemahan pada tubuh DPRD itu sendiri.

Berdasarkan pada realitas di atas, maka penulis mencoba untuk mengkaji persoalan ini ke dalam sebuah jurnal ilmiah, dengan harapan agar permasalahan-permasalahan tersebut di atas, dapat ditemukan apa yang menjadi penyebab utama sehingga persoalan lemah atau tidak maksimalnya fungsi pengawasan DPRD dapat ditemukan dan dibuktikan secara ilmiah.dengan mengangkat dalam sebuah jurnal yang bertajuk "' efektifitas fungsi Pengawasan DPRD terhadap Perjanjian antara Pemerintah dengan pihak ketiga di Kabupaten Sinjai. 
Dikson Junus, Pengembangan Kapasitas Dinas KesehatanKabupaten Gorontalo|59

\section{KAJIAN TEORI}

\section{Konsep Pengawasan}

Untuk menjamin terselenggaranya pemerintahan daerah yang baik (Good lokal Governance), diperlukan penerapan sistem pengawasan yang jelas, tepat dan legitimate, agar penyelenggaraan pemeritahan daerah dapat berlangsung secara efisien,efektif, bersih dan bertanggung jawab,serta bebas dari KKN (LAN: 143.2008). Pemerintahan daerah sebenarnya merupakan sub sistem dari pemerintahan nasional, sehingga pengawasan terhadap pemerintahan daerah juga merupakan bagian integral dari sistem pemerintahan nasional. Pengawasan penyelenggaraan pemerintahan daerah ditujukan untuk menciptakan pemerintahan yang efisien, efektif berorientasi pada pencapaian visi dan misi. Dengan pengawasan tersebut diharapkan dapat memberikan masukan bagi pengambilan keputusan untuk: (1) menghentikan atau meniadakan kesalahan, penyimpangan, penyelewengan, pemborosan dan ketidakadilan; (2) mencegah terulangnya kembali kesalahan,penyimpangan penyelewengan, pemborosan, hambatan dan ketidakadilan tersebut; dan (3) mendapatkan cara-cara yang lebih baik atau membina yang telah baik untuk mencapai tujuan dalam melaksanakan tugas pokok dan fungsi organisasi dan pencapaian visi dan misi organisasi dalam penyelenggaraan pemerintahan daerah. Sedangkan manfaat terpenting dari pengawasan adalah: (1) tersedianya bahan informasi bagi manajemen tentang situasi nyata dalam mana organisasi berbeda; (2) dikenalinya faktorfaktor pendukung terjadinya operasionalisasi rencana dengan efesinsi dan efektivitas; (3) pemahaman tentang berbagai faktor yang menimbulkan berbagai kesulitan dalam penyelenggaraan berbagai kegiatan operasionalisasi; (4) langkah-langkah apa yang segera dapat diambil untuk menghargai kinerja yang memuaskan; dan (5) tindakan preventif apa yang segera akan dilakukan agar deviasi dari standar tidak terus berlanjut. Sedangkan sasaran dari pengawasan adalah: (1) agar pelaksanaan tugas umum pemerintahan dilakukan secara tertib berdasarkan aturan perundang-undangan yang berlaku serta berdasarkan sendi-sendi kewajaran penyelenggaraan pemerintahan agar tercapai daya guna, hasil guna dan tepat guna yang sebaikbaiknya; dan (2) agar pelaksanaan pembagunan dilakukan sesuai dengan rencana dan program pemerintah serta peraturan perundang-undangan yang berlaku sehingga tercapai sasaran yang telah ditetapkan (LAN: 144. 2008).

Menurut Sujamto (1987:19) pengawasan merupakan proses yang berlanjut yaitu dilaksanakan terus menerus, sehingga dapat memperoleh hasil pengawasan yang berkesinambungan .Menurut Moekijat (1990: 19) mendefinisikan bahwa pengawasan adalah suatu proses yang menentukan tentang apa yang diselenggarakan sejalan dengan rencana. Sarwoto memberi pengertian pengawasan sebagai kegiatan manager yang mengusahakan agar pekerjaan-pekerjaan terlaksana sesuai dengan rencana yang ditetapkan atau hasil yang dikehendaki. Menurut Mondy R.Wayne et.Al (1991:488) adalah Controling is the process of comparing actual performance with standards and taking any necessary corrective action. Artinya bahwa pengendalian merupakan proses dalam membandingkan pencapaian standar yang diperlukan standar korektif. 
60|Ad'ministrare, Vol. 3 No. 1, 2016

Hal ini senada dengan pendapat Syamsi (1998:108) yang mengatakan bahwa pengawasan adalah fungsi manajemen yang mengusahakan agar pekerjaan kegiatan terlaksana sesuai dengan rencana, instruksi, pedoman, patokan peraturan atau hasil yang telah ditetapkan sebelumnya. Sedangkan menurut Ramli (1985:2) mengemukakan bahwa: pengawasan diartikan sebagai usaha menentukan apa yang sedang dilaksanakan dengan cara menilai prestasi yang dicapai dan kalau terdapat kesalahan maka diadakan usaha perbaikan, sehingga semua hasil yang tercapai sesuai rencana.

Arifin abdul Rahman dalam Situmorang dan Juhir (1994: 15) mengatakan bahwa pengawasan adalah:

a. Untuk mengetahui apakah segala sesuatu berjalan dengan baik rencana yang ditetapkan.

b. Untuk mengetahui apakah segala sesuatu telah berjalan sesuai dengan instruksi seeta prinsip-prinsip yang telah ditetapkan.

c. Untuk mengetahui apakah kelemahan, kesulitan dan kegagalannya, sehingga dapat diadakan perubahan -perubahan untuk memperbaiki dan mencegah perulangan kegiatankegiatan yang salah.

d. Untuk mengetahui apakah sesuatu berjalan efisien,apakah tidak dapat diadakan perbaikanperbaikan lebih, sehingga mendapat efisiensi yang lebih besar.

Me Farland memberikan definisi pengawasan, (Control) sebagai berikut:

"control is proces by with an executive gets the performance of hisubordinates to correspond as closely as posible to chosen plans,orders, objectives, or policies. Artinya pengawasan adalah suatu proses dimana pimpinan ingin mengetahui apakah hasil pelaksanaan pekerjaan yang dilakukan oleh bawahannya sesuai dengan rencana, perintah,tujuan atau kebijakan yang telah ditentukan, pengawasan harus berpedoman pada: 1) Rencana (Planning) yang telah diputuskan, 2) Perintah (Order) terhadap pelaksanaan pekerjaan, 3) Tujuan (Goal).

\section{Gambar 1. Proses Pengawasan}

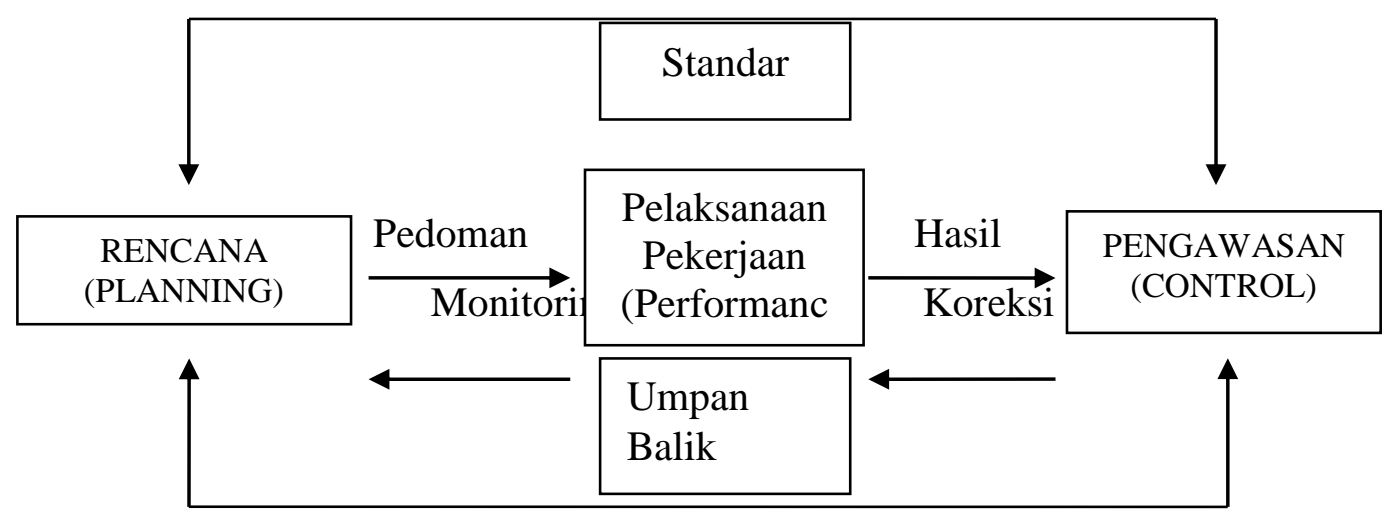

Sumber: Moekijat dalam Mc. Farland, (1990:18) 
Pengawasan itu dilakukan untuk mencegah atau untuk memperbaiki kesalahan, penyimpangan, ketidak sesuaian, penyelewengan dan lainnya yang tidak sesuai dengan tugas dan wewenang yang telah ditentukan. Jadi maksud pengawasan bukan mencari kebenaran terhadap hasil pelaksanaan pekerjaan.

James A.F. Stoner /Charles Wankel (1986: 65) menyatakan bahwa pengawasan adalah suatu upaya yang sistematis untuk menetapkan kinerja standar pada perencanaan, untuk merancang sistem umpan balik informasi, untuk membandingkan kinerja aktual dengan standar yang telah ditentukan, untuk menetapkan apakah telah terjadi penyimpangan dan mengukur signifikansi penyimpangan tersebut, serta untuk mengambil tindakan perbaikan yang diperlukan untuk menjamin bahwa semua sumber daya organisasi telah digunakan seefektif dan seefisien mungkin guna mencapai tujuan organisasi. Definisi tersebut mengacu pada unsur-unsur pokok proses pengawasan. Adapun langkah-langkah dalam pelaksanaan pengawasan sebagaimana telah dikemukakan oleh James A.F.Stoner/Charles Wankel (1986:69) sebagaimana dapat diperlihatkan pada gambar 2 berikut ini:

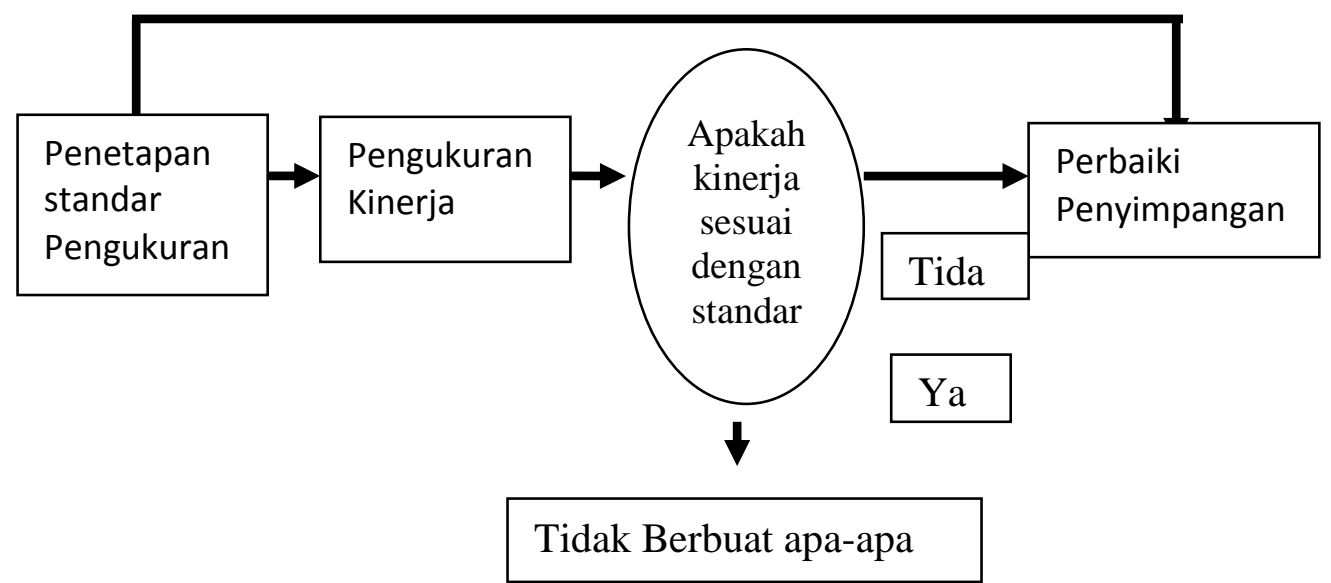

Gambar 2. Langkah-langkah proses Pengawasan

Selanjutnya Strong dan Smith (1989:75), menyatakan bahwa tanpa tegaknya sistem pengawasan yang memadai, kecil kemungkinannya suatu manajemen akan berhasil, meskipun dalam manajemen itu telah ada perencanaan yang baik tentang tujuan yang akan dicapai, organisasi yang kuat, para pelaksana yang cakap dan motivasi yang bergairah.

Senada dengan apa yang dikemukakan oleh Strong dan Smit, Massie (1971) menyatakan bahwa pengawasan merupakan "Pengukur Kinerja" yang sedang berjalan memandunya ke depan kearah yang telah ditentukan, esensi pengawasan terletak pada 
$62 \mid$ Ad'ministrare, Vol. 3 No. 1, 2016

pengecekan kegiatan-kegiatan yang telah dilaksanakan dibandingkan dengan hasil yang diinginkan yang telah ditetapkan dalam proses perencanaan. Sesuai dengan pernyataan yang telah dikemukakan oleh beberapa ahli tersebut di atas, maka Hariadi Darmawan (1998) menyatakan bahwa pengawasan adalah segenap kegiatan untuk meyakinkan dan menjamin bahwa pekerjaan dilakukan sesuai dengan rencana yang telah ditentukan, kebijakankebijakan yang telah digariskan dan petunjuk teknis dan operasional yang telah diberikan, dalam rangka pelaksanaan rencana tersebut secara efisien dan efektif, pengawasan harus mampu menjadi alat kendali dan alat ukur terhadap proses dan hasil kerja yang ingin dicapai, menilai pelaksanaan kegiatan (Kinerja) serta mengadakan tindakan perbaikan dan penyusuaian yang dipandang perlu dan sedini mungkin.

Lebih lanjut dikatakan bahwa sesungguhnya pengawasan itu bertujuan untuk: (1) menjamin ketepatan pelaksanaan kegiatan agar sesuai dengan rencana, kebijakan dan petunjuk operasional, serta ketaat- asasan terhadap peraturan perundang-undangan yang benar-benar mencerminkan rasa keadilan masyarakat; (2) Menjamin kelancaran dan terwujudnya kepuasan masyarakat atas mutu/kualitas nilai barang atau jasa/pelayanan yang dihasilkan; (3) menyerasikan dan menetapkan koordinasi pelaksanaan kegiatan yang saling terkait; (4) mencegah pemborosan dan penyelewengan atau penyalahgunaan wewenang; (5) membina kepercayaan, penghargaan dan kepatuhan masyarakat terhadap kepemimpinan dan pembinaan instansi teknis terkait.

\section{Konsep Fungsi dan Pengawasan DPRD}

\section{Fungsi Dewan Perwakilan Rakyat Daerah (DPRD)}

Membahas secara mendalam tentang fungsi dan peran lembaga legislatif, maka secara teoritis ada beberapa pandangan ahli antara lain adalah Pendapat Miriam Budiardjo,(2000:182183) bahwa untuk dapat mengemban tugas sebagai wakil rakyat, legislatif memiliki fungsi utama, yakni: Pertama Menentukan Policy (Kebijaksanaan) dan membuat undang-undang, untuk itu sebagai wakil rakyat diberi hak inisiatif untuk merubah rancangan undang-undang yang disusun oleh pemerintah, dan hak budget, Kedua Mengontrol badan eksekutif dalam arti menjaga semua tindakan eksekutif sesuai dengan kebijaksanaan-kebijaksanaan yang telah ditetapkan, maka untuk menyelenggarakan tugas ini, lembaga legislatif diberik hak-hak kontrol khusus.

Joseph Lapalombara (1974:135), mengatakan bahwa anggota legislatif sebagai basis perpanjangan tangan rakyat dalam kehidupan politik memiliki lima fungsi, yakni: " Rule Making, (Menetapkan undang-undang), Representation (Perwakilan atau saluran aspirasi), agregation of Interest (Penyatuan Kepentingan) Political socialisation and education (sosialisasi politik dan Pendidikan), Supervision and Secrutiny (supervisi dan Penyidikan) kemudian lebih lanjut La Palombara menjelaskan bahwa ada banyak faktor yang mempengaruhi kualitas anggota Legislatif dalam melaksanakan fungsinya sebagai wakil rakyat, Rule Orientation (Orientasi Kekuasaan), Nature and Timing of Issue ( Sumber dan Momentum yang menentukan 
Dikson Junus, Pengembangan Kapasitas Dinas KesehatanKabupaten Gorontalo|63

issu itu berkembang), Behavior, enviromental and Political (Lingkungan dan Politik) semua faktor tersebut saling melengkapi.

Sedangkan Imawan (dalam Jimung, dkk .2004) mengatakan bahwa lembaga Legislatif memiliki empat fungsi, yaitu: " Pertama, Fungsi Legislasi (Perundang-undangan) meliputi: pembuatan aturan sendiri, Menjadi mediator antara kepentingan rakyat dengan pemerintah," Kedua Fungsi budget (Penganggaran) meliputi: Merancang dan menentukan arah serta aktifitas pemerintah, fungsi ini berkaitan dengan kemampuan DPRD dalam mendistribusikan sumber daya lokal (termasuk anggaran dan sebagainya) sesuai skala prioritas yang secara politis telah ditetapkan, Ketiga Fungsi pengawasan (Kontrol) Meliputi: aktifitas memfasilitasi perkembangan kepentingan masyarakat berdasarkan agenda yang telah ditentukan oleh pemerintah, lembaga perwakilan menilai apakah aktifitas pemerintah masih selaras dengan aspirasi masyarakat serta memastikan bahwa perkembangan aspirasi masih bisa diakomodir dalam rencana kerja pemerintah, Keempat adalah Regulator Konflik, meliputi aktifitas menampung dan menyerap konflik kepentingan yang berkembang di dalam masyarakat sehingga konflik pada tataran masyarakat dapat berubah menjadi konflik internal lembaga perwakilan sebagai bagian dari sebuah sistem politik.

\section{Pengawasan Dewan Perwakilan Rakyat Daerah (DPRD)}

Bertitik tolak dari hakekat DPRD sebagai lembaga legislatif daerah, maka pengawasan terhadap eksekutif merupakan fungsi lain DPRD. Pengawasan dilakukan melalui penggunaan hak-hak yang dimiliki oleh DPRD. Tuntutan akan pelaksanaan fungsi pengawasan menjadi sangat penting, sebagaimana dikemukakan oleh Effendi dalam Syukriy (2004). "Pelaksanaan fungsi pengawasan oleh badan perwakilan rakyat terhadap perumusan pelaksanaan kebijaksanaan-kebijaksanaan Negara amat menarik perhatian peneliti ilmu politik maupun peneliti administrasi negara oleh karena itu merupakan suatu indikator dari pelaksanaan kedaulatan rakyat yang menjadi inti sistem demokrasi Pancasila."

Terlepas dari ada atau tidaknya penyelewengan atau pemborosan dan inefisiensi, berbagai bentuk pengawasan, termasuk pengawasan legislatif tetap diperlukan karena fungsi ini merupakan salah satu fungsi intern dalam pengelolaan pembangunan. bahwa pengawasan legislatif adalah salah satu pencerminan demokrasi Pancasila dan karena itu perlu dilaksanakan agar rakyat dapat berpartisipasi dalam pengelolaan pembangunan.

Dengan demikian, pengawasan oleh DPRD terhadap penyelenggaraan pemerintahan sangat penting guna menjaga adanya keserasian penyelenggaraan tugas pemerintah dan pembangunan yang efisien dan berhasil guna serta dapat menghindari dan mengatasi segala bentuk penyelewengan yang dapat merugikan atau membahayakan hak dan kepentingan negara, daerah dan masyarakat. Fungsi pengawasan oleh DPRD adalah salah satu bentuk pengawasan yang sangat penting diperlukan pelaksanaannya dalam pengelolaan pembangunan, sebagai refleksi partisipasi masyarakat dan hakekat kedaulatan rakyat yang dilaksanakan lewat para wakilnya dalam lembaga perwakilan, sebagai hakekat demokrasi Pancasila.

Legislatif atau DPRD merupakan lembaga yang menurut undang-undang memiliki posisi strategis dalam melakukan fungsi pengawasan terhadap pemerintah Daerah, Realitas 
64|Ad'ministrare, Vol. 3 No. 1, 2016

fungsi pengawasan tersebut kadangkala tidak maksimal. Hal ini dikarenakan oleh ketidakpahaman para legislator untuk menjabarkan peraturan perundang-undangan yang berlaku. Bahkan yang lebih ekstrim, fungsi pengawasan hanya digunakan sebagai alat untuk menyorot kesalahan eksekutif bukan pada peran untuk membantu eksekutif dalam menjalankan tugas pemerintahan, sebagaimana tertuang pada pasal 3 ayat 1 UU Nomor 32 tahun 2004 tentang Pemerintahan Daerah.

Salah satu fungsi legislatif yang sentral menjadi perhatian dan perbincangan semua kalangan adalah fungsi pengawasan. Dalam Ilmu administrasi, fungsi pengawasan mengandung tindakan lembaga yang bersifat Prefentif dan repressif yang mengandung makna mengevaluasi dan mengawasi program-program pemerintah daerah. Oleh karena mengandung makna mengevaluasi, maka konsekwensinya adalah semua kebijakan pemerintah daerah dalam menjalankan program-programnya, tidak serta merta termentahkan oleh karena sebuah pengawasan, akan tetapi yang perlu ditegaskan adalah fungsi pengawasan tidak memiliki kekuatan represif atau eksekutor untuk membatalkan sebuah program pemerintah sepanjang program yang dimaksud untuk pembangunan daerah.

Menurut Malik dalam Jimung (2004), mengatakan bahwa Pengawasan sering disamakan artinya dengan kata "Kontrol, supervisi, monitoring dan auditing" dalam konteks pengawasan yang dilakukan oleh DPRD yang salah satu fungsinya adalah pengawasan terhadap pelaksanaan berbagai kebijakan publik di daerah yang dilaksanakan oleh lembaga eksekutif, apakah kebijakan itu telah dilakukan sesuai dengan Rencana Kerja Pemerintah Daerah (RKPD), sehingga kata yang tepat untuk digunakan untuk mewakili istilah "Pengawasan " adalah Oversight, yang berarti pengamatan dan pengarahan sebuah tindakan berdasarkan kerangka yang ditentukan.

Dalam kontek DPRD sebagai lembaga politik, fungsi pengawasan yang dijalankan merupakan bentuk pengawasan politik yang lebih bersifat strategis dan bukan pengawasan teknis adminstrasi. Hal inilah yang membedakan fungsi pengawasan yang dilakukan oleh DPRD dengan lembaga lain seperti, Badan Pemeriksa Keuangan (BPK), Bawasda, Inspektorat lainnya. Fungsi pengawasan DPRD bersifat politis, yang paramaeternya adalah Program Kerja Pemerintah Daerah (PKPD) yang ditetapkan setiap tahun berdasarkan Rencana Program Jangka Menengah Daerah (RPJMD) yang merupakan formalisasi pejaabaran visi dan misi aatau janji politik kepala daerah dan wakil kepala daerah ketika berkampanye.

Pada pasal 343, ayat 1 Point c Undang-undang Nomor 27 Tahun 2009, Tentang Susunan dan Kedudukan MPR,DPR,DPD dan DPRD dinyatakan bahwa DPRD sebagai sebuah Lembaga, bukan sebagai individual dalam melakukan pengawasan terhadap Pelaksanaan Peraturan Daerah, kebijakan dan keputusan Pemerintah daerah serta APBD. Penekanan DPRD sebagai sebagai sebuah lembaga di sini, saangat penting, mengingat didalam undang-undang ini tidak ada satu ayat yang menyatakan bahwa anggota DPRD secara pribadi-pribadi mempunyai fungsi dan kewenangan. Artinya fungsi pengawasan yang dimiliki oleh anggota DPRD adalah fungsi secara Lembaga, artinya bahwa DPRD dalam melakukan pengawasan harus dilakukan melalui kelengkapan DPRD. Oleh karena itu, langkah yang paling mendasar untuk menguatkan fungsi pengawasan adalah: Pertama Merumuskan tentang ruang lingkup batasan Kerja dan prioritas Pengawasan, Kedua, merumuskan standar akuntabilitas yang baku dalam pengawasan 
Dikson Junus, Pengembangan Kapasitas Dinas KesehatanKabupaten Gorontalo|65

yang dapat diterima oleh lembaga yang menjadi sasaran dan mitra pengawasnnya, karena dengan memiliki dan memahami standar akuntabilitas yang baku, DPRD dapat menghindarkan diri dari politisasi fungsi pengawasan dan terhindar dari dampak negatif yang mungkin ditimbulkannya.Ketiga, rumusan standar atau ukuran yang jelas untuk menentukan sebuah kebijakan publik dikatakan berhasil, gagal atau menyimpang dari RKPD yang telah ditetapkan, Keempat, Merumuskan rekomendasi serta tindak lanjut dari hasil pengawasan, baik itu pada tingkat kebijakan, proyek atau kasus-kasus tertentu. Semua itu harus dirumuskan dalam tata tertib DPRD, sehngga alat kelengkapan DPRD dalam melakukan pengawasan memiliki pemahaman meskipun berasal dari fraksi yang berbeda-beda

Sejak berlakunya Undang-undang Nomor 32 Tahun 2004 tentang pemerintahan daerah, dimana kepala daerah dan wakil kepala Daerah dipilih langsung oleh masyarakat, terdapat perubahan fundamental dalam hal hubungan kerja antara pemerintah daerah dengan DPRD. Sebagai mitra Legislatif, Pemerintah tidak lagi bertanggung jawab kepada DPRD, melainkanhanya menyampaikan Laporan Keterangan Pertanggungjawaban (LKPJ) kepada DPRD dalam bentuk Progres Report Kinerja Pemerintah daerah selama satu tahun anggaran, oleh karena itu pengawasan yang dilakukan DPRD, tidak lagi dalam bentuk menerima atau menolak, oleh karena itu tindakan memposisikan Pemerintah daerah dengan DPRD pada dua kutub yang berbeda di era otonomi daerah seperti sekarang ini adalah sebuah tindakan yang tidak tepat, karena sebagaimana telah dijelaskan dalam Undang-Undang Nomor 32 Tahun 2004 tentang Pemerintahan daerah khususnya pada pasal 19 ayat (2) bahwa Penyelenggara Pemerintahan di daerah adalah Pemerintah Daerah Dan Dewan Perwakilan Rakyat Daerah (DPRD)

\section{METODE PENELITIAN}

Penelitian ini adalah penelitian dalam bentuk studi kasus (Case Study) yakni suatu penelitian yang dilakukan dengan cara studi yang mendalam tentang model Pengawasan DPRD Terhadap Pemerintah di Kabupaten Sinjai. Adapun alasan memilih Sinjai sebagai lokus penelitian, karena ahir-ahir ini Kabupaten Sinjai sering mendapat sorotan dari masyarakat, tentang tidak jelas dan tidak efektifnya model pengawasan yang dijalankan oleh pihak DPRD terhadap Pemerintah daerah di Kabupaten Sinjai. Karena penelitian ini adalah penelitian kualitatif, maka instrumen Penelitian yang digunakan adalah peneliti sendiri berfungsi sebagai instrumen penelitian. Selain itu peneliti menggunakan instrumen penelitian lain seperti Pedoman Observasi,pedoman wawancara dan Pedoman studi dokumentasi serta dokumen.

\section{HASIL DAN PEMBAHASAN}

Setelah melakukan pengkajian dan analisis secara mendalam terhadap fungsi dan model pengawasan yang dijalankan oleh anggota DPRD kabupaten Sinjai periode keangotaan 2014-2019, terhadap pemerintah, dengan mengajukan beberapa konsep mekanisme pengawasan legislatif yang telah disusun secara sistematis oleh peneliti 
66|Ad'ministrare, Vol. 3 No. 1, 2016

dengan menyandingkan hasil pemikiran dan konsep yang telah dikemukakan oleh Ali Rokhman ; 2009. Dimana dalam konsep pemikirannya telah mengemukakan konsep pengawasan dengan urutan sebagai berikut, 1) Membuat agenda Pengawasan; 2)Penerapan Metodologi pengawasan; 3) Membangun jaringan; 4) Menjalankan Pengawasan; 5) Membuat laporan; 6) Menindak lanjuti Laporan dan ; 7) Penilaian terhadap LKPJ Bupati.

Dari ketuju konsep yang telah dikemukakan di atas, setelah dilakukan penelitian dengan menganalisis penerapannya dalam setiap fase atau tahapan pengawasan yang dijalankan oleh anggota DPRD kabupaten Sinjai, maka data menunjukkan bahwa tidak satupun dari ketuju indikator tersebut diterapkan secara maksimal, sehingga dengan demikian peneliti dapat berkesimpulan bahwa mekanisme dan model pengawasan yang telah dijalankan oleh anggota DPRD belum memilki konsep yang baku, sehingga menurut peneliti, untuk meningkatkan kinerja DPRD dalam menjalankan fungsi pengawasan, khsusunya pengawasan terhadap perjanjian antara pemerintah dengan pihak ketiga di kabupaten Sinjai, perlu dibuat suatu mekanisme pengawasan yang baku untuk dijadikan sebagai acuan dalam menjalankan fungsi pengawasan DPRD.

Penerapan ketuju indikator atau konsep dari mekanisme pengawasan yang telah dikemukakan di atas, bukanlah suatu jaminan yang pasti akan berjalannya fungsi pengawasan DPRD secara efektif, tapi paling tidak akan menjadi patron bagi setiap anggota DPRD dalam menjalankan fungsinya sebagai lembaga pengawasan yang bersifat politis. Karena pengawasan DPRD bukan merupakan pengawasan fungsional sehingga mekanisme dan tatacara pelaksanaannya tidak diatur secara detail sebagaimana halnya dengan pengawasan terhadap APBD dan pengawasan terhadap PERDA, sehingga dengan demikian pengawasan terhadap perjanjian antara pemerintah dengan pihak ketiga sangat mungkin terjadinya salah interpretasi dalam proses menjalankannya.

Untuk menghindari terjadinya kesalahan dalam menjalankan fungsi pengawasan terhadap perjanjian antara pemerintah dengan pihak keiga, maka perlu dilakukan penyempurnaan terhadap konsep-konsep tersebut melalui mekanisme pengawasan yang diawali dengan peroses pelibatan pihak-pihak yang terkait pada saat pelaksanaan musrenbang di setiap strata pemerintahan yang dimulai dari tingkat desa hingga ke tingkat musrenbang tingkat kabupaten, kemudian dilanjutkan dengan penertapan agenda pengawasan, penentuan Metode pengawasan, membangun jaringan dengan berbagai pihak, melaksanakan pengawasan, membuat laporan, melakukan tindak lanjut pengawasan serta menilai LKPJ bupati pada setiap ahir tahun anggaran atau ahir masa jabatan, untuk lebih jelasnya dapat dilihat pada bagan mekanisme pengawasan yang telah diformulasi oleh peneliti pada gambar 3 


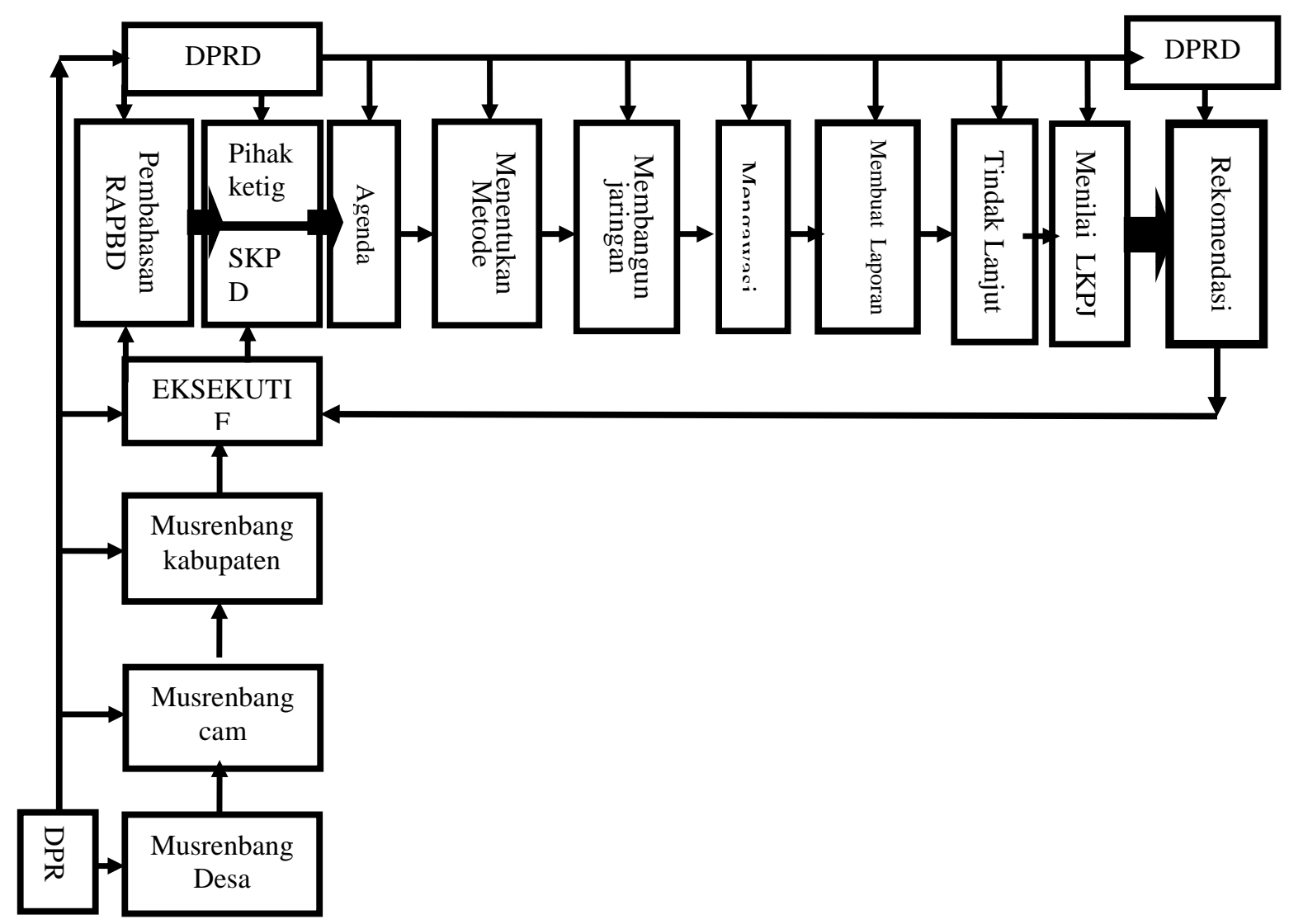

\section{Gambar 3 \\ Bagan atau Model Mekanisme Pengawasan DPRD di Kabupatens Sinjai}

Dari model pengawasan yang telah dikemukakan pada bagan 1 (satu) tersebut di atas, tergambar secara sistematis alur mekanisme pengawasan terhadap pemerintah dalam menjalankan fungsi pengawasan terhadap pemerintah daerah, untuk lebih jelasnya akan diuraikan secara teknis bagaimana mengimplementasi secara praktis model tersebut kedalam praktek pengawasan DPRD sebagai berikut:

\section{Tahap Musrenbang}

Pada tahapan ini, adalah merupakan tahap perencanaan pembangunan yang secara hirarkis, terbagi atas tiga tingkatan untuk kategori perencanaan pembangunan di tingkat kabupaten, yakni musrenbang tingkat Desa atau kelurahan, murenbang tingkat 
68|Ad'ministrare, Vol. 3 No. 1, 2016

kecamatan dan musrenbang tingkat kabupaten/Kota yang dalam pelaksanannya tentunya dihadiri oleh pihak-pihak yang terkait, berdasarkan tingkatan pemerintahan yang menjadi pelaksana kegiatan tersebut, tidak terkecuali anggota DPRD harus hadir dan mengikuti pelaksanaan kegiatan musrenbang dalam kapasitasnya sebagai wakil rakyat yang bertugas untuk memberikan masukan sekaligus mengawali proses pengawasan terhadap pemeintah dalam melakukan perencanaan pembangunan, sebab selama ini banyak keluhan dari masyarakat, khususnya pada pelaksanaan Musrenbang di tingkat desa/kelurahan dan kecamatan seringkali apa yang telah direncanakan tidak diakomodir oleh pemerintah daerah dan seolah kegiatan musrenmbang hanya sekedar formalitas saja, sehingga dengan demikian tentunya sangat diharapkan kehadiran dari anggota DPRD pada setiap tingkatan musrenbang sebagai representasi dari masyarakat untuk membantu menyalurkan aspirasi masyarakat bawah. Sehingga dengan demikian kehadiran anggota DPRD pada setiap pelaksanaan murenmbang adalah dalam rangka mengawal aspirasi rakyat.

\section{Tahap Pembahasan RAPBD}

Setelah tahap perencanaan telah selesai, maka kegiatan selanjutnya adalah dilakukan pembahasan RAPBD, dimana kegiatan ini dilakukan oleh Pemerintah atau (SKPD) terkait bersama dengan DPRD, dalam peroses pembahasan ini, peran DPRD adalah sebagai mitra dari pemerintah daerah sekaligus sebagai representasi dari masyarakat untuk memperjuangkan apa yang menjadi kebutuhan dan aspirasi dari masyarakat yang diwakilinya.

\section{Tahap Perjanjian dengan Pihak ketiga (Tender)}

Tahapan selanjutnya setelah pembahasan RPABD dinyatakan selesai yang ditandai dengan telah ditetapkannya APBD tahun berjalan, maka kegiatan selanjutnya adalah peroses pelelangan proyek (Tender) yang dilakukan oleh Pemerintah atau SKPD terkait yang dihadiri oleh peserta tender atau pihak ketiga dan tidak terkecuali anggota DPRD harus mengikuti kegiatan tersebut, dimana kehadiran anggota DPRD adalah dalam kedudukannya sebagai lembaga yang memiliki kewenangan untuk melakukan pengawasan terhadap pemerintah dalam melakukan perjanjian dengan pihak ketiga.

\section{Penentuan Agenda Pengawasan}

Penentuan agenda pengawasan adalah suatu kegiatan yang dilakukan oleh DPRD untuk menentukan agenda dan jadual pengawasan, yang menetapakan kapan pengawasan itu dimulai, siapa yang berkompeten dan komisi apa yang berhak untuk melakukan pengawasan, tentu penetapan agenda pengawasan ini dilakukan untuk 
Dikson Junus, Pengembangan Kapasitas Dinas KesehatanKabupaten Gorontalo|69

menghindari terrjadinya kesimpangsiuran dalam menjalankan fungsi pengawasan, sebab selama ini sering terjadi kesalahpahaman dalam melakukan pengawasan karena tidak adanya penentuan dan penetapan agenda sebelum melakukan pengawasan.

\section{Penentuan Metode Pengawasan}

Penentuan metode pengawasan, adalah merupakan hal yang sangat penting dan menentukan tingkat keberhasilan dan efektifitas fungsi pengawasan, sebab perlu diketahui bahwa metode pengawasan politik dengan metode pengawasan fungsional sangat berbeda, hal inilah yang sering menjadi pemicu munculnya kesalahan dan kesimpangsiuran pengawasan yang dijalankan oleh DPRD sebab seringkali teknik pengawasan fungsional ingin diterapkan dalam pengawasan politik, padahal substansinya sangat berbeda, DPRD sebagai lembaga pengawasan politik memiliki beberapa metode pengawasan, antara lain; 1) Pengaduan; 2)Rapat dengar pendapat umum (Public Hearing); 3).Kegiatan kunjungan kerja dan 4) Rapat kerja Komisi dengan Pemerintah., tentunya keempat metode pengawasan ini harus dipahami benar oleh anggota DPRD, agar tidak salah kapra dalam menjalankan fungsi pengawasan.

\section{Membangun jaringan}

Membangun jaringan dalam menjalankan fungsi pengawasan bagi DPRD juga merupakan hal yang sangat penting, sebab DPRD memiliki keterbatasan untuk melakukan pengawasan, baik itu keterbatasan dari segi kuantitas, keterbatasan kualitas maupun keterbatasan dari segi waktu, oleh karena itu jalan yang harus ditempuh adalah membangun jaringan kerjasama dengan pihak-pihak yang dianggap memiliki kemampuan untuk membantu dalam menjalankan fungsi pengawasan politik, oleh karena itu DPRD harus membangun jaringan dengan Partai Politik, LSM, Perguruan Tinggi, media massa, pihak kepolisian dan aparat penegak hukum lainnya, sebab perlu dipahami bahwa kewenangan DPRD dalam melakukan pengawasn tidak sampai kepada proses justifikasi, tetapi hanya sebatas melakukan hearing atau mengarahkan pemerintah jika terjadi kesalahan atau kekeliruan dalam menjalankan tugas-tugas pemerintahan dan pembangunan.

\section{Melaksanakan Pengawasan}

Pelaksanaan pengawasan terhadap perjanjian antara pemerintah dengan pihak ketiga secara praktis berlangsung pada saat kegitatan tender berlangsung dan berakhir pada setiap tahun anggaran atau sampai pada saat proyek tersebut telah diterima oleh pemerintah selaku pemilik atau pengguna proyek. Dan yang bertindak sebagai 
pelaklsana pengawasan adalah anggota DPRD dari setiap komisi yang menjadi mitra dari pemeintah atau SKPD yang bersangkutan dan didalam menjalankan fungsi pengawasan tentunya setiap anggota DPRD bertanggung jawab kepada ketua komisi, selanjutnya bertanggung jawab kepada ketua melalui komisi, seluruh hasil pengawasan yang telah dilakukan oleh anggota DPRD harus dipertanggung jawabkan kepada pimpinan dengan tujuan agar setiap anggota DPRD yang telah melakukan pengawasan tidak sekedar bertindak tanpa harus dibarengi oleh prinsip-prinsip akuntabilitas, sebab selama ini ada banyak kasus pengawasan yang dilaksanakan oleh anggota DPRD tanpa dilandasi oleh pertanggung jawaban sehingga banyak diantaranya anggota DPRD menjalankan fungsi pengawasan berdasarkan pemahaman sendiri, sehingga seringkali salah dalam bertindak, yang pada ahirnya akan merugikan masyarakat.

\section{Membuat Laporan}

Agar pelaksanaan pengawasan DPRD terhadap perjanjian antara pemerintah dengan pihak ketiga dapat berjalan secara efektif dan dapat dipertanggungjawabkan secara administratif, maka kegiatan pengawasan yang telah dilaksanakan harus dibuatkan laporan sebagai pertanggung jawaban kepada pimpinan komisi atau pimpinan DPRD ataupun kepada pihak-pihak yang terkait dengan pelaksanaan pengawasan, termasuk menyampaikan laporan kepada bupati sebagai atasan langsung dari instansi yang melakukan pelanggaran, dengan harapan bahwa bupati sebagai atasan dapat memberikan arahan atau teguran jika bahwahannya terbukti melakukan pelanggaran. Salah satu kelemahan pengawasan yang telah dijalankan oleh anggota DPRD adalah karena jarang membuat laporan sehingga seringkali hasil pengawasan tidak ditindak lanjuti oleh pihak yang berkompeten.

\section{Tindak Lanjut Hasil Pengawasan}

Setiap pengawasan yang telah dilakukan oleh DPRD tentunya tidak hanya berakhir pada pembuatan atau penyampaian dalam bentuk laporan, akan tetapi jika terbukti ada temuan pelanggaran yang dilakukan oleh pihak yang diawasi, maka selanjutnya harus ditindak lanjuti dengan melakukan monitoring dengan tujuan agar apa yang menjadi temuan di lapangan dapat dihentikan atau dapat dicegah melalui pengawasan secara berkala. Selain itu,memonitoring juga dilakukan untuk mengetahui apakah kasus yang telah menjadi temuan mendapatkan tindak lanjut dari pimpinan atau pihak-pihak yang berkompoten untuk memberi justifikasi terhadap permasalahan yang terjadi. 
Dikson Junus, Pengembangan Kapasitas Dinas KesehatanKabupaten Gorontalo $\mid 71$

\section{Menilai Laporan Keterangan Pertanggung jawaban (LKPJ)}

Tahapan terakhir dari mekanisme pengawasan terhadap perjanjian antara pemerintah dengan pihak ketiga adalah menilai laporan keterangan pertanggung jawaban (LKPJ) bupati pada setiap ahir tahun anggaran atau ahir masa jabatan, dalam kegiatan ini DPRD melakukan penilaian terhadap LKPJ bupati, apakah pelaksanaan kegiatan yang telah dilakukan selama satu tahun sesuai dengan rencana sebelumnya atau tidak, jika ternyata apa yang telah dilakukan selama satu tahun anggaran ada ketidak sesuaian dengan rencana yang telah ditetapkan sebelumnya, maka pihak DPRD dapat memberikan rekomendasi untuk dilakukan perbaikan. Karena berdasarkan aturan perundangundangan apabila dalam LKPJ bupati ternyata terdapat kekurangan atau ketidak sesuaian dengan rencana sebelumnya, maka DPRD tidak lagi memiliki kewenangan untuk menerima atau menolak LKPJ, tetapi hanya sebatas mendengarkan.

Kelemahan dari sistem ini, membuka peluang bagi pemerintah atau bupati untuk melakukan penyelewengan, karena kalaupun terjadi kesalahan dalam pembacaan LKPJ, maka DPRD hanya sebatas memberi rekomendasi untuk dilakukan perbaikan dan tidak perlu disampaikan dalam forum resmi dihadapan sidang DPRD, tetapi cukup dengan penyamapaian secara tertulis bahwa telah dilakukan perubahan sesuai dengan saransaran DPRD.

Berdasarkan pada tahapan-tahapan pengawasan yang telah dikemukakan di atas, maka hasil ahir dari seluruh rangkaian yang ada adalah membuat rekomendasi perbaikan dan penyempurnaan terhadap tahapan-tahapan tersebut jika sekiranya terdapat penyimpangan atau kekurangan selama berlangsungnya kegiatan yang berkaitan dengan perjanjian antara pemerintah dengan pihak ketiga di kabupaten Sinjai.

\section{PENUTUP}

Model pengawasan DPRD terhadap pemerintah daerah di kabupaten Sinjai, tidak berjalan sebagaimana mestinya atau tidak efektif, karena tidak adanya mekanisme yang telah ditetapkan sebelumnya untuk digunakan sebagai pedoman atau acuan dalam menjalankan fungsi pengawasan, sehingga mekanisme yang dijalankan hanya berdasarkan pada persepsi masing-masing anggota DPRD. 
72 |Ad'ministrare, Vol. 3 No. 1, 2016

\section{DAFTAR PUSTAKA}

Isra, Saldi, 2002 Potret Lembaga Perwakilan Rakyat, Jurnal ilmu Pemerintahan,edisi 18 Jakarta.

Jimung, Martinus. 2004. Kemampuan anggota Dewan dalam Melaksanakan Fungsi Legislasi dan Pengawasan, Jurnal Sosiosains, Vol.17 no.3ommunication skills.Addison Wesley Lungman Australia PTY Limited

LaPalombara, Josep. 1974. Legislatures Fungctions and Behavior" Dalam Ensiclopedia of democracy (Congressional Quarterly)

Lembaga Administrasi Negara. 2008. Manajemen Pemerintahan Daerah, Jakarta: LAN.

Miles, M.B. dan Huberman, M., 1992 Analisis data Kualitatif, Terjemahan oleh Tjetjep Rohendi Rohidi, Jakarta UI Press.

Malik, M.,2008. Fungsi Pengawasan Dewan Perwakilan Rakyat Daerah: antara pengawasan Politik dan Manuver Politik, http//Cetak bangka pos.com.

Matthews, Donald R. 2006, Legislative recruitmen, and Legislatif Careers, Legislative Studies Quarterly. USA

Rohkman Ali, 2009, Teknik Pengawasan Dewan Perwakilan Rakyat Daerah, http://www.docstoc.com/docs/ (diakses 18Agustus 2011)

Silaban, Pasaman. 2009. Kinerja Eksekutif dan Legislatif dalam Peroses penganggaran dan implikasinya terhadap Perwujudan Good Governance Jurnal Legislatif diakses April 2011

Undang-undang No.32 Tahun 2004 tentang Pemerintah Daerah,Jakarta: Pusat Infodata Indonesia.

Undang-undang RI No. 27 Tahun 2009, Tentang MPR,DPR DPD dan Dewan

Perwakilan rakyat Daerah (DPRD), Jakarta : Pancausaha 